\title{
The Effect of Solvency, Profitability, and Working Capital on Firm Value: Case Studies on Industrial Companies in IDX 2015-2019
}

\author{
Andini Nurwulandari \\ Universitas Nasional, Jakarta, Indonesia \\ Email: andinmanajemen@gmail.comm
}

\begin{abstract}
The publication of the financial statements (issuers) of the company is a time waiting for investors in the capital market, as investors will find out the progress of issuance, as a consideration for purchasing or selling their own shares, when publishing these financial reporting statements. This research uses quantitative techniques with descriptive interpretation. Data sources include company-owned financial data reports collected from the IDX and published online, as well as conducting library analysis by collecting data from the writing of related books and journals. The type of data used in the study is secondary data from 2015-2019 which was collected through a purposive sampling process. Statistical Descriptive Analysis and Mulicollinearity Test. From this research, it can be seen that the rate of working capital turnover, solvency and capital structure affect firm value, while profitability does not affect firm value.
\end{abstract}

Keywords: Solvency, Profitability, Working Capital, Firm Value, Influence.

\section{A. INTRODUCTION}

One of the information that investors need is information on financial statements or annual financial reports. At least once a year, a public company is obliged to issue an annual financial report to investors on the stock exchange (Bisman, Jaenuri \& Kusworo, 2019) For investors, annual financial reports are a source of various kinds of information, especially company balance sheets and income statements (Adnyana \& Nurwuandari, 2020). Past studies have therefore demonstrated the importance of the annual statements of the company as a source of investment (Eri \& Riyan, 2020).

There are in general two approaches, namely fundamental analysis and technical analysis, often used by investors to analyze and value stock on the capital market. The economic analysis is a fundamental analysis, the conditions of industry and of the business to consider the company's value. The fundamental analysis focuses on key data for determining whether stock prices have been accurately assessed in the Company's financial statement (Kaddumi \& Ramadhan, 2012). The main aim of the analysis is to determine whether the stock value is lower or too high. The stock price in the stock market is said to be underpriced is less than the fair price or the value it should be (intrinsic value), and a stock is said to be overpriced if the share price in the stock market is greater than its intrinsic value (Khidmat \& rehman, 2014). 
Profitability assessment is an assessment of the condition of a bank's ability to generate earnings to support operations and capital (Noer, Saribanon \& Nurwulandari, 2017). Rentability (earnings) not only shows the quantity and trend of earnings, but also the factors that affect the availability and quality of earnings (Maarif, Sarjono \& Utami, 2020). The profitability ratio of a company shows the comparison between the profits obtained by the company with the assets or capital needed to generate these profits (Mohamad \& Saad, 2010). Profitability means that the company can generate profit over a certain period using the aggregated assets or capital used in the operations of the company (Mawaddah \& Nurwulandari, 2019).

The ability for the company to make profits during a given period can be measured with a view to the success of the company and to the productivity of its assets (Padachi, 2006). Working capital must therefore be effectively and productive as one of the most important components of assets to increase profitability of the company (Nurwulandari \& Darwin, 2020).

Working capital is the company's total existing assets or can also be used as funds to fund the daily operation of the company (Panigrahi, 2014). Or it can also be seen from another definition, Total value of the investments of the Company into short-term assets, such as cash, accounts receivable, advance payments or the total value of the investment of the Company in current assets is the working capital of the Company, less current liabilities (net working capital) (Chrispina, Ponisan, Tago \& Mkiibi, 2014). current assets that represent an investment in the execution of a business or working capital that rotates from one form to another, are cash / bank, cashable securities (for example demand deposits, checks, deposits), accounts receivable and inventories. turnover rate does not exceed one year or the period of normal operation of the company (Prabowo \& Yolanda, 2020).

The solvency measure itself is often used to measure the efficiency of a company's use of capital by comparing profits and capital in operations (Singh \& Pandey, 2008). The policy on the capital structure of the company is one of the factors that affect the increase in firm value. The capital structure of the company is a combination of the company's long-term funds (Putri \& Nurwulandari, 2020).

The solvency ratio in this study is measured in a ratio scale, namely the Debt to Equity Ratio (DER). The greater the DER indicates that the capital structure uses more debt than its own capital (Singh \& Asress, 2011). Financing with debt has 3 important implications (1) obtaining funds through debt allows shareholders to maintain control over companies with limited investment, (2) creditors view equity, or funds paid by owners, to provide a safety margin, so that if shareholders only giving a small part of the total financing, so the company risk is mostly on the creditors; (3) If the company obtains a higher loan funded investment return than interest payments, the return on the owner's capital will be higher. If the return on a borrowed investment compares to the interest, the return on the capital of the owner will be lower (Wilis \& Nurwulandari, 2020). 
In addition, the scale of the company is also a factor that affects the company's profitability. Company scale shows the total assets owned by the company. A company that is large-scale and its shares are widespread, usually has its own strength in dealing with business problems and the company's ability to generate higher profits because its business or business is supported by large assets so that company constraints such as adequate equipment and so on can be overcome.

\section{B. METHOD}

This research uses quantitative techniques with descriptive interpretation. Data sources include company-owned financial data reports collected from the IDX and published online, as well as conducting library analysis by collecting data from the writing of related books and journals. The type of data used in the study is secondary data from 2015 to 2019 which was collected through a purposive sampling process. Statistical Descriptive Analysis and Mulicollinearity Test.

\section{RESULT AND DISCUSSION}

\section{Sample Company Background}

Table 1 Research Sample Companies

\begin{tabular}{|c|c|}
\hline Code & Company Name \\
\hline ADES & Akhsa Wira International \\
\hline AISA & Tiga Pilar Sejahtera Food \\
\hline CEKA & Cahaya Kalbar \\
\hline DLTA & Delta Djakarta \\
\hline ISMA & Indofood Sukses Makmur \\
\hline MBIN & Multi Bintang Indonesia \\
\hline MAYI & Mayora Indah \\
\hline SELA & Sekar Laut \\
\hline SITO & Siantar Top \\
\hline BIPP & Bhuwanatala Indah Permai \\
\hline BKSL & Sentul City \\
\hline CTRA & Ciputra development \\
\hline DART & Duta Anggada Reality \\
\hline DILD & Intiland Development \\
\hline DUTI & Duta Pertiwi \\
\hline ELTY & BakrieLand Development \\
\hline LPCK & Lippo Cikarang \\
\hline LPKR & Lippo Karawaci \\
\hline
\end{tabular}

Source: Processed Data 


\section{Solvability}

The following is the formula when applying the solvency ratio: Debt ratio $=$ total debt/assets $\times 100 \%$ Debt/equity ratio = total amount of debt/equity (equity) $x$ $100 \%$ the time ratio earned is = before taxes earnings and before taxes costs $\times 100 \%$. Table 2 below gives the results of the research calculation:

Table 2 Descriptive Statistics for Firm Solvency

\begin{tabular}{|c|c|c|c|c|c|}
\hline & N & Minimum & Maximum & Mean & Std. Deviation \\
\hline 2015 & 10 & .2768 & 2.7134 & 1.358041 & .7861256 \\
2016 & 10 & .3455 & 2.6651 & 1.360988 & .6661089 \\
2017 & 10 & .2783 & 8.5414 & 1.694997 & 2.3251908 \\
2018 & 10 & .1443 & 2.3827 & 1.171454 & .7060945 \\
2019 & 10 & .2252 & 1.7321 & .972506 & .4316227 \\
Valid N (listwise) & 10 & & & & \\
\hline
\end{tabular}

Source: processed data

From the results of the processed data in table 2 above, it can be concluded that the largest average Solvency in the Food and Beverage Industry is seen in 2017, which is 1.694997. The average conditions for the sample companies' total debt to shares were, therefore, the best in 2017, whereas the standard default value in 2017 was 2,325,1908. In 2017, solvency for the most varied by a value of 8.5414 in all sample firms, and the lowest was 0.2783. This condition also indicates that the sample companies' solvency status fluctuates where the maximum company's total debt-to-equity distance is compared with the company's distance which has a minimum ratio of full debt-to-equity.

\section{Rentability}

In general, the profitability ratio can be calculated by comparing the profits generated with the business capital issued. The profitability ratio can be used to measure when making a decision about the problem of meeting the company's financial needs. Table 3 below shows the results of the research calculation:

Table 3 Descriptive Statistics for Company Profitability

\begin{tabular}{|c|c|c|c|c|c|}
\hline & $\mathrm{N}$ & Minimum & Maximum & Mean & Std. Deviation \\
\hline 2015 & 11 & -231.7568 & 41.6884 & -12.968350 & 74.6756593 \\
2016 & 11 & -28.3046 & 65.5807 & 13.864405 & 23.1668144 \\
2017 & 11 & 5.2331 & 343.5964 & 45.338438 & 93.8784730 \\
2018 & 11 & 4.1869 & 94.9934 & 23.673399 & 26.0731180 \\
2019 & 11 & 4.9641 & 96.6941 & 23.090268 & 26.4661771 \\
Valid N & 11 & & & & \\
\hline
\end{tabular}

Source: processed data 
From the processed data in table 3 above, it can be concluded that the largest average Profitability in the Food and Beverage Industry was seen in 2017, which was 45.338438. This means that in 2017 the condition of the average net profit (EAT) to total own capital in the sample companies looked the best, while the largest standard deviation value occurred in 2017 with a standard deviation of 93.8784730. This means that in 2017 the rentability of all sample companies varied the most with a value of 343.5964 and the smallest was 5.2331. This condition also shows that the condition of the sample companies fluctuates in terms of the distance between companies that have a maximum ratio of net income (EAT) to total equity when compared to the distance in companies that have a minimum ratio of net income (EAT) to total equity.

\section{Working Capital}

The current ratio, that is, current assets, is calculated by dividing the current liabilities. A ratio higher than 1 means that the present assets are higher and higher the ratio is better. The results of the research calculations are presented in Table 4 below:

Table 4 Descriptive Statistics for the Company's Industrial Working Capital

\begin{tabular}{|c|c|c|c|c|c|}
\hline & $\mathrm{N}$ & Minimum & Maximum & Mean & Std. Deviation \\
\hline 2015 & 11 & -2860.56 & 893.71 & -12.0862 & 1054.13075 \\
2016 & 11 & -3658.85 & 1254.53 & -156.5524 & 1599.38204 \\
2017 & 11 & -565.96 & 2066.35 & 533.6202 & 656.53522 \\
2018 & 11 & -5246.47 & 1259.89 & -38.2627 & 1738.41665 \\
2019 & 11 & -48580.71 & 9749.43 & -3097.9083 & 15409.92042 \\
Valid N (listwise) & 11 & & & & \\
\hline
\end{tabular}

Source: Processed data

From the data in Table 4, it can be concluded that the average working capital was shown in 2017 in the largest companies, which was 533.6202. This means that in 2017 the condition of the average sales of current assets minus current debt in the sample companies looked the best, while the largest standard deviation value occurred in 2019 with a standard deviation of 15409,92042. This means that in 2019 the working capital of all sample companies varied the most with a value of 9749.43 and the smallest was -48580.71 . This condition also shows that the working capital condition of the sample company fluctuates, where the distance in the company that has a ratio of sales to total current assets minus maximum current debt is compared to the distance in a company that has a ratio of sales to current assets minus minimal current debt. 


\section{The Value Of The Company}

Compact value can be measured by using a ratio known as the valuation ratio. Appraisal ratio is a performance evaluation ratio of the shares of companies traded on the capital market (go public). Table 5 below shows the results of the research calculations:

Table 5 Descriptive Statistics for Value of Industrial Firms

\begin{tabular}{|c|c|c|c|c|c|}
\hline & $\mathrm{N}$ & $\begin{array}{c}\text { Minimu } \\
\mathrm{m}\end{array}$ & Maximum & Mean & $\begin{array}{c}\text { Std. } \\
\text { Deviation }\end{array}$ \\
\hline 2015 & 10 & 15.710 & 4172.672 & 827.43510 & 1273.282298 \\
2016 & 10 & 16.726 & 4702.486 & 882.18648 & 1406.884258 \\
2017 & 10 & 18.960 & 9574.441 & 1492.92862 & 2843.379093 \\
2018 & 10 & 18.670 & 18750.581 & 3088.67808 & 5703.447649 \\
2019 & 10 & 38.246 & 30495.383 & 4675.06903 & 9156.756446 \\
Valid N (listwise) & 10 & & & & \\
\hline
\end{tabular}

Source: Processed data

From the processed data in table 5 above, it can be concluded that the largest average Company Value in the Food and Beverage Industry is seen in 2019, amounting to 4675.06903. This means that the average market value to book value for the sample enterprises is best achieved in 2019, while the largest standard deviation value is 9156.756446 in 2019. This means that in 2019 the Firm Value of all sample companies varied the most with a value of 30495,383 and the smallest was 38,246 . This condition also shows that the condition of the sample firm's value fluctuates, where the distance within an enterprise with a maximum market value to a book value relative to distance in an enterprise has a minimum book value-tomarket ratio.

\section{Descriptive statistics}

Table 6 shows all variables in this study with descriptive statistics. The distribution of data from the studied sample is known through descriptive analyzes, and the relation between variables is determined through correlation analysis.

Table 6 Descriptive Statistics

\begin{tabular}{|l|c|c|c|c|c|}
\hline & $\mathrm{N}$ & Minimum & Maximum & Mean & Std. Deviation \\
\hline The value of the & 110 & 15.00 & 30495.37 & 1215.2740 & 3585.43453 \\
Company & & & & & \\
Solvability & 110 & .08 & 8.54 & 1.2730 & 1.21916 \\
Rentability & 110 & -240.86 & 343.70 & 10.2601 & 38.84076 \\
Working capital & 110 & -48580.80 & 9749.43 & -254.9695 & 4589.35735 \\
Valid N (listwise) & 110 & & & & \\
\hline
\end{tabular}

Source: Processed data 
The table shows the samples used in the regression analysis. The sample as a whole is 110 . Solvency, profitability and equity are the company's values. It is known from the table above that 110 data from financial reports and list of sample stock prices of companies in 2015-2019 were analyzed.

Liquidity is used to determine the ability of a company to fulfill its short-term obligations. During the period of surveying (2015-2019), the average solvency value was $40.1627 \%$. Looking at 40.1617 percent of the average liquidity, the average company can fulfill its 40.1627 percent short-term obligations. The solvency measure is the average of 1.2630 times the total debt to the total assets.

\section{Multicollinearity Test}

The multi-channel test is done to determine if an intercorrelation or collinearity between independent variables is presented in a regression model.

Table 7 Coefficients Multikoliniearitas

\begin{tabular}{|c|c|c|c|}
\hline \multirow{2}{*}{\multicolumn{2}{|c|}{ Model }} & \multicolumn{2}{c|}{ Collinearity Statistics } \\
\cline { 2 - 4 } & (Constant) & Tolerance & VIF \\
\hline \multirow{4}{*}{1} & Rentability & .735 & 1.389 \\
\cline { 2 - 4 } & Solvability & .758 & 1.347 \\
\cline { 2 - 4 } & Working Capital & .954 & 1.069 \\
\cline { 2 - 4 } & Dummy & .384 & 2.680 \\
\hline
\end{tabular}

a. Dependent Variable: The value of the company

Source: Data processed from Eviews.

Table 7 shows the multi-linearity of the various variables, which have changed over the 0.8 range to support the multi-linear model and had a positive impact on firms in 2019 as a result of the 2017 sampling.

\section{CONCLUSION}

The results of the data analysis concluded that, for statistical testing to be conducted in the form of Multicollinearity Test, the data in this study fulfilled the normal assumption of normality. Data testing find that the rate of working capital turnover, solvency, and capital structure impacts the value of the company, whereas profitability does not affect the value of the company.

\section{REFERENCES}

1. Adnyana, M., \& Nurwulandari, A. (2020). Empirical examination of intersectoral linkages between tourism and regional economy by using the social accounting matrix.

2. Bisman., Hamdi, M., Jaenuri, A., \& Kusworo. (2019). Pengaruh Partisipasi Masyarakat dan Kinerja Pengelola terhadap Kualitas Pelayanan Penyediaan Sarana Air Minum dan Sanitasi Berbasis Masyarakat di Kabupaten Rokan Hulu. Papatung: Jurnal Ilmu Administrasi Publik, Pemerintahan dan Politik, 2(3), 118. 
3. Eri, N., \& Riyan, A. (2020). Bauran Pemasaran (Product, Price, dan Place) Pada Analisis Gisty Hijab Olshop. AKSELERASI: Jurnal Ilmiah Nasional, 2(3), 1-16.

4. Kaddumi, T. A., \& Ramadan, I. Z. (2012). Profitability and working capital management: The Jordanian case. International Journal of Economics and Finance, 4(4), 217-226.

5. Khidmat, W., \& Rehman, M. (2014). Impact of liquidity \& solvency on profitability chemical sector of Pakistan. Economics management innovation, 6(3), 34-67.

6. Maarif, S., Sardjono, T. W., \& Utami, Y. W. (2020). National Early Warning Score Parameters at the Emergency Department as In Hospital Cardiac Arrest Predictors. International Journal of Science and Society, 2(4), 1-9.

7. Mawaddah, T., \& Nurwulandari, A. (2019). Pengaruh Indeks KLCI, STI, SET dan PSEI (Intergasi AFTA) Terhadap IHSG. Oikonomia: Jurnal Manajemen, 14(2).

8. Mohamad, N. E. A. B., \& Saad, N. B. M. (2010). Working capital management: The effect of market valuation and profitability in Malaysia. International journal of Business and Management, 5(11), 140.

9. Noer, M., Saribanon, N., \& Nurwulandari, A. (2017). Business Model Analysis of Natural Production Forest with Sustainable Forest Management Approach. Geografia-Malaysian Journal of Society and Space, 13(1).

10. Nurwulandari, A., \& Darwin, M. (2020). Heywood Case Data Statistik Menggunakan teknik Respesifikasi Model. Nucleus, 1(2), 74-84.

11. Padachi, K. (2006). Trends in working capital management and its impact on firms' performance: an analysis of Mauritian small manufacturing firms. International Review of business research papers, 2(2), 45-58.

12. Panigrahi, C. M. A. (2014). Relationship of working capital with liquidity, profitability and solvency: a case study of ACC Limited. Asian journal of management research, 4(2), 308-322.

13. Prabowo, H. R. J., \& Yolanda, S. F. (2020). Analysis of the Leading Sector and the Effect to Regional Minimum Wage (UMSK): A Case Study in Cimahi City, Indonesia. ENDLESS: International Journal of Future Studies, 3(2), 64-96.

14. Putri, E., \& Nurwulandari, A. (2020). Analisis reaksi Pasar Modal Bagi Perusahaan Dalam index IDX30 terhadap Kemenangan Donald Trump Pada Pemilihan Presiden Amerika Serikat. Oikonomia: Jurnal Manejemen, 15(2).

15. Singh, J. P., \& Pandey, S. (2008). Impact of Working Capital Management in the Profitability of Hindalco Industries Limited. ICFAI Journal of Financial Economics, 6(4).

16. Singh, K., \& Asress, F. C. (2011). Determining working capital solvency level and its effect on profitability in selected Indian manufacturing firms. International Journal of Research in Commerce, Economics \& Management.

17. Wilis, R. A., \& Nurwulandari, A. (2020). The effect of E-Service Quality, E-Trust, Price and Brand Image Towards E-Satisfaction and Its Impact on E-Loyalty of Traveloka's Customer. Jurnal Ilmiah MEA (Manajemen, Ekonomi, $\mathcal{E}$ Akuntansi), 4(3), 1061-1099. 